DEPARTMENT OF THE INTERIOR

U.S. GEOLOGICAL SURVEY

\title{
GEOLOGIC MAP OF THE ANAWALT QUADRANGLE,
} WEST VIRGINIA-VIRGINIA.

By Virgil A. Trent and Frank D. Spencer 


\section{GEOLOGIC MAP SYMBOLS}

COMMONLY USED ON MAPS OF THE UNITED STATES GEOLOGICAL SURVEY

(Special symbols are shown in explanation)

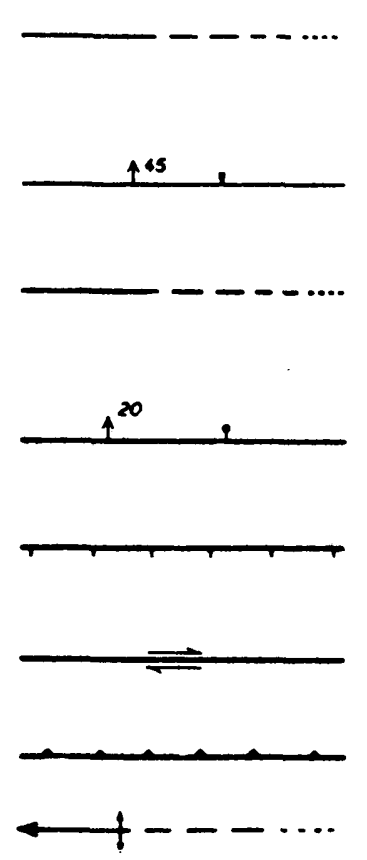

Contact - Dashed where approximately located; short dashed where inferred; dotted where concealed

Contact - Showing dip; well exposed at triangle

Fault - Dashed where approximately located; short dashed where inferred; dotted where concealed

Fault, showing dip - Ball and bar on downthrown side

Normal fault - Hachured on downthrown side

Fault - Showing relative horizontal movement

Thrust fault - Sawteeth on upper plate

Anticline - Showing direction of plunge; dashed where approximately located; dotted where concealed

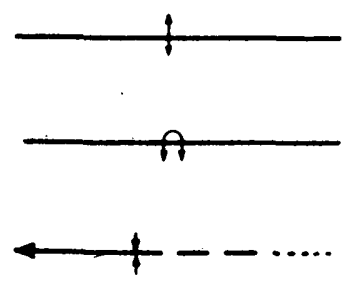

Asymmetric anticline - Short arrow indicates steeper limb

Overturned anticline - Showing direction of dip of limbs

Syncline - Showing direction of plunge; dashed where approximately located; dotted where concealed

Asymmetric syncline - Short arrow indicates steeper limb

Overturned syncline - Showing direction of dip of limbs

Monocline - Showing direction of plunge of axis

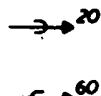

Minor anticline - Showing plunge of axis

Minor syncline - Showing plunge of axis
Strike and dip of beds - Ball indicates top of beds known from sedimentary structures

$\stackrel{70}{ }$ Inclined $\oplus$ Horizontal

+ Vertical $\underset{40}{40}$ Overturned

Strike and dip of foliation $\leftarrow 20$ Inclined $\rightarrow$ Vertical $\uparrow$ Horizontal

Strike and dip of cleavage

$\stackrel{15}{ }$ Inclined $\longrightarrow$ Vertical If Horizontal

Bearing and plunge of lineation

$15 \hookleftarrow$ Inclined $\bullet$ Vertical $\longleftrightarrow$ Horizontal

Strike and dip of joints $\ldots . .4$ Inclined $\rightarrow$ Vertical $\rightarrow$ Horizontal

Note: planar symbols (strike and dip of beds, foliation or schistosity, and cleavage) may be combined with linear symbols to record data observed at same locality by superimposed symbols at point of observation. Coexisting planar symbols are shown intersecting at point of observation.

Shafts

$\square$ Vertical $\square$ Inclined

Adit, tunnel, or slope

-Accessible ٪ Inaccessible

$\times$ Prospect

Quarry

$x$ Active 3 Abandoned

Gravel pit

$X$ Active $\nsucc$ Abandoned

Oil well

- Drilling $\phi$ Shut-in $\phi$ Dry hole

Gas Show of gas abandoned

- Oil Show of oil 